\title{
MIR133A1 Pre-miRNA
}

National Cancer Institute

\section{Source}

National Cancer Institute. MIR133A1 Pre-miRNA. NCI Thesaurus. Code C82766.

MIR133A1 is an oligoribonucleotide that is encoded by the human MIR133A1 gene and has a role in the regulation of gene expression. 